\title{
Germination Studies in Different Guava (Psidium guajava L.) Cultivars
}

\author{
Praveen Jholgiker, Manga Bade* and Anil Sabard
}

Department of Fruit science, KRCCH, Arabhvi, University of Horticultural Sciences, Bagalkot

*Corresponding author:

\section{A B S T R A C T}

\section{Keywords \\ Guava, Seed, Germination, Vigour index \\ Article Info \\ Accepted: \\ 26 April 2017 \\ Available Online: \\ 10 May 2017}

An investigation was carried out on germination studies in different cultivars of guava during 2011 -2012. Germination studies revealed that the least number of days for the initiation of germination (17.67 days) and 50 per cent of germination (24 days) was noted in cv. Sardar. Maximum germination per cent $(88.00 \%)$, shoot length $(8.43 \mathrm{~cm})$, seedling root length $(7.54 \mathrm{~cm})$, fresh weight $(3.14 \mathrm{~g})$, dry weight $(1.57 \mathrm{~g})$ of seedling were recorded in $\mathrm{cv}$. SR -4 , whereas the highest vigour index was noted in cv. SW -4 .

\section{Introduction}

Guava belongs to family Myrtaceae, is one of the commercial fruit crop grown in tropical and sub topical region. It is known for its nutritive value being rich in minerals and vitamin ' $\mathrm{C}$ ' content. Most of guava plantations in India are seedling origin. Traditionally, it is mostly propagated from seed (Zamir et al., 2003), which is easy and a cheap method (Ruehle, 1948). In recent years asexual methods such as inarching, veneer, soft wood grafting (Shashikumar, 2010), patch budding (Patel et al., 2005) and layering (Rymbai and Reddy, 2011) are being practiced for large scale multiplication. Seed propagation is necessary for raising rootstocks for grafting and budding practices. Graft success and vigour of graft largely depends on quality of rootstock. Huge variability in growth pattern of seedling plantation has been reported in guava (Shashikumar, 2010). There is a need to identify a suitable rootstock with good vigour and wider adoptability. Keeping these points in view an experiment was conducted to study the germination behavior in different guava cultivars (varieties and local landraces) under shade house conditions.

\section{Materials and Methods}

The experiment was carried out during 201112 at the Department of Fruit Science, Kittur Rani Channamma College of Horticulture, Arabhavi, University of Horticultural Sciences, Bagalkot, Karnataka state. The experiment was laid out in Completely Randomized Design with 16 treatments comprising seeds of varieties and local land races replicated thrice. Hundred seeds were used per treatment per replication. Seeds were soaked overnight in a solution of $\mathrm{GA}_{3}$ $250 \mathrm{ppm}$ and sowed in pots with FYM and 
red soil in equal portion as potting mixture. Observations were recorded on seed weight, seedling growth parameters like number of days taken for the initiation of germination and seedling shoot and root length per seedling. Five seedlings were selected at randomly for determining fresh and dry weight. Vigour index of seedling was computed by adopting the formula suggested by Abdul Baki and Anderson (1970).

\section{Results and Discussion}

Guava seeds are known to be recalcitrant and germination of seeds is uncertain due to hard seed coat (Singh, 1967). Traditional methods of propagation like grafting and budding necessarily required good healthy and vigorous rootstock raised from seeds, there is a existence of huge variability in seed traits including seed shape, size, number among different popular varieties and local races. There is a need to screen this variability in seed for its germination and growth responses keeping in view to identify suitable rootstock for large scale propagation through grafting and budding. In the context of conflicting review from literature on seed germination behavior, the present experiment was carried and executed. The assessment of results obtained from this investigation reveals that there is a varied response for germination and growth of seedlings.

Table.1 Variation in seed germination behavior among different cultivars of guava under Arabhavi conditions

\begin{tabular}{|l|c|c|c|c|}
\hline \multicolumn{1}{|c|}{ Treatment details } & $\begin{array}{c}\text { 100 Seed } \\
\text { weight }(\mathbf{g})\end{array}$ & $\begin{array}{c}\text { Days taken for } \\
\text { initiation of } \\
\text { germination }\end{array}$ & $\begin{array}{c}\text { Days taken for } \\
\mathbf{5 0} \text { \% of } \\
\text { germination }\end{array}$ & $\begin{array}{c}\text { Per cent } \\
\text { germination }\end{array}$ \\
\hline $\mathrm{T}_{1}-$ Sardar & 1.48 & 17.67 & 24.00 & 76.67 \\
\hline $\mathrm{T}_{2}-\mathrm{GW}-1$ & 1.01 & 23.67 & 30.67 & 56.50 \\
\hline $\mathrm{T}_{3}-\mathrm{GW}-2$ & 1.63 & 20.33 & 25.67 & 62.00 \\
\hline $\mathrm{T}_{4}-\mathrm{GW}-3$ & 1.15 & 22.00 & 28.67 & 0.00 \\
\hline $\mathrm{T}_{5}-\mathrm{GR}-1$ & 1.25 & 22.00 & 26.67 & 72.33 \\
\hline $\mathrm{T}_{6}-\mathrm{GR}-2$ & 1.23 & 23.67 & 27.33 & 35.33 \\
\hline $\mathrm{T}_{7}-\mathrm{GR}-3$ & 1.12 & 22.67 & 26.00 & 68.67 \\
\hline $\mathrm{T}_{8}-\mathrm{CIW}-1$ & 1.20 & 24.67 & 29.67 & 78.00 \\
\hline $\mathrm{T}_{9}-\mathrm{CIW}-3$ & 1.15 & 22.33 & 27.67 & 71.00 \\
\hline $\mathrm{T}_{10}-\mathrm{CIW}-4$ & 1.29 & 25.00 & 29.67 & 53.33 \\
\hline $\mathrm{T}_{11}-\mathrm{CIW}-5$ & 0.80 & 23.00 & 29.67 & 62.00 \\
\hline $\mathrm{T}_{12}-\mathrm{SWY}-1$ & 0.75 & 23.00 & 27.67 & 71.33 \\
\hline $\mathrm{T}_{13}-\mathrm{SW}-4$ & 1.25 & 22.33 & 26.00 & 40.33 \\
\hline $\mathrm{T}_{14}-\mathrm{SR}-4$ & 1.28 & 22.67 & 17.33 & 88.00 \\
\hline $\mathrm{T}_{15}-\mathrm{Allahabad}$ safed & 1.04 & 24.00 & 26.33 & 78.00 \\
\hline $\mathrm{T}_{16}-\mathrm{Safeda}$ & 0.87 & 25.00 & 32.67 & 76.67 \\
\hline $\mathrm{SEm} \pm$ & 0.02 & 0.47 & 2.23 & 8.39 \\
\hline $\mathrm{CD}$ @ 5\% & 0.07 & 1.37 & 6.44 & 24.18 \\
\hline $\mathrm{CV}$ (\%) & 0.60 & 2.50 & 10.72 & 26.12 \\
\hline
\end{tabular}


Table.2 Variation in seedling vigour among different cultivars of guava under Arabhavi conditions

\begin{tabular}{|c|c|c|c|c|c|c|}
\hline $\begin{array}{c}\text { Treatment } \\
\text { details }\end{array}$ & $\begin{array}{c}\text { Length } \\
\text { of root } \\
(\mathrm{cm})\end{array}$ & $\begin{array}{c}\text { Length } \\
\text { of shoot } \\
\text { (cm) }\end{array}$ & $\begin{array}{c}\text { Fresh } \\
\text { weight of } \\
\text { seedlings } \\
\text { (g) }\end{array}$ & $\begin{array}{c}\text { Dry } \\
\text { weight of } \\
\text { seedlings } \\
\text { (g) }\end{array}$ & $\begin{array}{l}\text { Difference } \\
\text { between } \\
\text { fresh and } \\
\text { dry weight } \\
\text { (g) }\end{array}$ & $\begin{array}{l}\text { Vigour } \\
\text { Index }\end{array}$ \\
\hline $\mathrm{T}_{1}-\mathrm{Sardar}$ & 5.86 & 8.12 & 2.34 & 1.49 & 0.85 & 622.93 \\
\hline $\mathrm{T}_{2}-\mathrm{GW}-1$ & 5.59 & 5.56 & 1.65 & 1.29 & 0.37 & 313.42 \\
\hline $\mathrm{T}_{3}-\mathrm{GW}-2$ & 6.73 & 8.18 & 2.62 & 1.58 & 1.04 & 513.56 \\
\hline$T_{4^{-}}$GW-3 & 1.11 & 1.25 & 0.46 & 0.40 & 0.06 & 0.00 \\
\hline $\mathrm{T}_{5}-\mathrm{GR}-1$ & 5.81 & 7.33 & 2.37 & 1.49 & 0.88 & 533.33 \\
\hline $\mathrm{T}_{6}-\mathrm{GR}-2$ & 3.21 & 4.39 & 1.17 & 0.87 & 0.30 & 228.65 \\
\hline $\mathrm{T}_{7}-\mathrm{GR}-3$ & 5.41 & 7.71 & 2.99 & 1.62 & 1.38 & 528.85 \\
\hline $\mathrm{T}_{8}-\mathrm{CIW}-1$ & 4.89 & 7.19 & 2.44 & 1.46 & 0.98 & 561.99 \\
\hline $\mathrm{T}_{9}-\mathrm{CIW}-3$ & 4.71 & 7.24 & 2.47 & 1.46 & 1.01 & 514.36 \\
\hline $\mathrm{T}_{10}-\mathrm{CIW}-4$ & 6.55 & 6.99 & 1.72 & 0.99 & 0.73 & 365.55 \\
\hline $\mathrm{T}_{11}-\mathrm{CIW}-5$ & 4.61 & 4.34 & 1.59 & 0.96 & 0.63 & 268.49 \\
\hline $\mathrm{T}_{12}-\mathrm{SWY}-1$ & 5.24 & 6.27 & 2.45 & 1.46 & 0.99 & 173.88 \\
\hline $\mathrm{T}_{13}-\mathrm{SW}-4$ & 3.22 & 5.31 & 1.71 & 1.01 & 0.69 & 749.44 \\
\hline $\mathrm{T}_{14}-\mathrm{SR}-4$ & 7.54 & 8.43 & 3.14 & 1.57 & 1.56 & 612.67 \\
\hline $\begin{array}{l}\mathrm{T}_{15} \text { - Allahabad } \\
\text { safed }\end{array}$ & 5.72 & 8.24 & 2.97 & 1.55 & 1.41 & 332.55 \\
\hline $\mathrm{T}_{16}-$ Safeda & 3.53 & 4.15 & 1.98 & 1.00 & 0.98 & 90.71 \\
\hline $\mathrm{SEm} \pm$ & 1.21 & 1.27 & 0.56 & 0.29 & 0.30 & 260.71 \\
\hline CD@ @ & 3.49 & 3.67 & 1.62 & 0.85 & 0.86 & 110.32 \\
\hline $\mathrm{CV}(\%)$ & 13.59 & 12.72 & 9.63 & 6.62 & 7.86 & 110.32 \\
\hline
\end{tabular}

The data pertaining to seed weight and germination behavior is presented in Table. 1 . Maximum 100 seed weight was recorded in GW - 2 (1.63g) followed by Sardar (1.48g), which was found associated with faster rate of germination as reflected by early initiation (17.67 and 20.33 days) and 50 percent germination (24.0 and 25.67 days) in cv. Sardar and GW -2 respectively. However there was no clear relation between seed weight and percent germination (Table.1).

Among the different cultivar the percent germination was highest in SR $-4(88.00 \%)$ followed by Allahabad safed (78.00\%), CIW $-1(78.00 \%)$ and Sardar $(76.67 \%)$. High rate of germination in there cultivars may be attributed to their better response to overnight soaking in $\mathrm{GA}_{3}-250$ ppm solution compared to other accessions. These observations corroborate with Singh and Soni (1998) who reported high per cent germination on water soaking for more than 12 hours in cv. Allahabad safed and Red fleshed. Similarly Birdar et al., (2005) suggested the treatment of chilling $+\mathrm{GA}_{3}-100 \mathrm{ppm}$ treatment to realize higher per cent germination in guava cv. Taiwan guava and Allahabad safed.

High percent germination in present germination of present investigation in few cultivars may be attributed to availability of moisture in seed, exogenous application of $\mathrm{GA}_{3}$ which might have helped to increase 
endogenous synthesis of $\mathrm{GA}_{3}$ (Ramchandra and Sheogovind, 1990) and trigger synthesis of hydrolyzing enzymes for conversion of starch to sugar making then available for developing embryo.

The interpretation of data pertaining to seedling growth (Table 2) also reflected vigorous growth in seedlings of $\mathrm{cv}$. SR -4 , Allahabad safed and Sardar as depicted by high values for shoot length $(8.43,8.24$ and $9.12 \mathrm{~cm})$ and root length $(7.54,5.72$ and 5.86 $\mathrm{cm})$ respectively. This may be attributed to the good response of these cultivars to $\mathrm{GA}_{3}-$ $250 \mathrm{ppm}$ treatment which might have stimulated easily investigation highlighted the suitability of cv. SR - 4, Allahabad safed and Sardar for raising rootstock.

\section{References}

Abdul Baki, A. A and Anderson, J. D., 1970, Viability and leaching of sugars from germinating barley. Crop Sci., 10: 31.34.

Biradar suryakanth, L., Mukunda, G. K. and Raghavendraprasad, G. C., 2005, Studies on germination in guava cvs. Taiwan guava and Allhabad safeda.
Karnataka J. Hort., 1(3): 47-50.

Ramchandra and Sheogovind., 1990, GA, thiourea, ethanol and acid treatment in relation to seed germination and seedling growth in guava (Psidium guajava L.). Prog. Hort., 22 (1-4): 40 43.

Rymbai, H. and Reddy, G. S. N., 2011, Influence of open field and polyhouse nursery on survival characters of rooted layers in guava (Psidium guajava L.). Life sciences Leaflets, 21: 996 - 1002.

Ruehle, G. D., 1948, A rapid method of propagating the guava. California Avocado Society. Yearbook, 33: 108112.

Singh, S and Soni. S.,1998, Effect of water and acid soaking periods on seed germination in guava. Punjab Hort. J.

Singh, R, 1967, Fruits, National Book trust of india, New Delhi, pp. 87 -88.

Shashikumar, 2010, Standardization of softwood grafting in guava (Psidium gujava L). M. Sc. (Hort.) Thesis, Univ. Agric. Sci., Dharwad.

Zamir, R., Khattak, G. S. S., Mohammad, T. and Ali, N., 2003, In vitro mutagenesis in guava (Psidium guajava L.). Pakistan J. Bot., 35 (5): 825-828.

\section{How to cite this article:}

Praveen Jholgiker, Manga Bade and Anil Sabard. 2017. Germination Studies in Different Guava (Psidium guajava L.) Cultivars. Int.J.Curr.Microbiol.App.Sci. 6(5): 2826-2829. doi: https://doi.org/10.20546/ijcmas.2017.605.319 